\title{
Persepsi Masyarakat Lombok Terhadap Seksologi Dalam Lontar Resi Sembina Pada Masa Grahasta Asrama
}

\author{
I Made Agus Yudhiarsana ${ }^{1}$, Ida Bagus Alit Arta Wiguna ${ }^{2}$, Ni Made Arini ${ }^{3}$ \\ ${ }^{123}$ Institut Agama Hindu Negeri Gde Pudja Mataram \\ 1yudhiarsana@iahn-gdepudja.ac.id
}

\begin{tabular}{l}
\hline Keywords: \\
\hline Public \\
perception; \\
Lombok; \\
Sexology; Lontar \\
Resi Sembina; \\
Grahasta \\
Asrama; \\
\hline
\end{tabular}

Kata Kunci:

Persepsi masyarakat; Lombok; Seksologi; Resi Sembina; Grahasta Asrama;

\begin{abstract}
Understanding the meaning and sanctity of sex as a biological need that has the same position as the need to eat and drink leads humans to their nature to fulfill sexual needs. To find out the understanding of the Hindu community in Lombok about the philosophical value of the discourse of intercourse in the text of Lontar Resi Sembina. This study used a descriptive type of research with a qualitative approach. In this study, we dissect a literary source in the form of lontar, which will then be linked to data on public perceptions of the teachings in the text of Lontar Resi Sembina. (1) Public understanding of Hindu religious teachings, especially regarding tattwa or the philosophical meaning of intercourse in living the life of Grahasta Asrama or having a household in Pagesangan Village, is still shallow. (2) almost all people in Pagesangan Village do not have literary sources that discuss sexual intercourse or kama tattwa. (3) there is a discrepancy between the public's view of the importance of fulfilling sexual libido as one of the expressions of kama in life, with the fulfillment of sources of information, both primary in the form of lontar literature, books, and other socialization media as well as supporting information sources in the form of the existence of Hindu intellectuals in the dissemination of tattwa teachings contained in the text of Lontar Resi Sembina.
\end{abstract}


tentang tattwa atau makna filsafat dari sanggama dalam menjalani kehidupan Grahasta Asrama atau berumahtangga di Kelurahan Pagesangan masih sangat rendah. (2) masyarakat di Kelurahan Pagesangan hampir seluruhnya belum memiliki sumber sastra yang membahas tentang sanggama atau kama tattwa. (3) terjadi ketidaksesuaian antara pandangan masyarakat akan pentingnya pemenuhan libido seksual sebagai salah satu ekspresi kama dalam kehidupan, dengan pemenuhan sumber informasi baik yang sifatnya utama dalam wujud sastra lontar, buku, dan media sosialisasi lainnya maupun sumber informasi penunjang berupa eksistensi kaum intelektual Hindu dalam penyebaran ajaran tattwa yang terkandung dalam teks Lontar Resi Sembina.

\section{Pendahuluan}

Fenomena yang terjadi di masyarakat utamanya di kota-kota besar saat ini sangatlah memprihatinkan, kesadaran akan makna seks yang salah dan keliru telah membentuk pola pikir negatif tersendiri bagi perkembangan psikologi dan moral para remaja (Wiguna, 2019). Adanya penyalahgunaan media elektronik sebagai perkembangan teknologi komunikasi yang didukung fasilitas bluetooth dan internet, menyebabkan Ipod, Laptop atau computer, Hand phone, dan media elektronik lainnya menjadi media yang sangat efektif dalam penyebaran video porno. Pada beragam kasus, baik kekerasan seksual, pemerkosaaan, seks pranikah dan peristiwa amoral lainnya terpicu karena gamblangnya dan mudahnya penyebaran media-media berbau porno di masyarakat.

Perkembangan teknologi informatika dewasa ini bagai pisau bermata dua, memberikan dampak positif dan negatif bagi perkembangan pola tingkah laku dan pembentukan moral para remaja saat ini (Sudarsana, 2018). Sisi negatif perkembangan teknologi informatika telah memberikan dampak yang signifikan pada perkembangan remaja menuju pada degradasi moral masyarakat, khususnya para remaja. Dari penelitian dalam bentuk Disertasi, dengan judul "persepsi remaja tentang hubungan seksualitas pranikah di Kota Denpasar" (Duarsa, 2009) serta dengan judul "sikap remaja terhadap seks bebas di Kota Negara" (Adikusumo, 2005) dapat kita ukur adanya penurunan kesadaran remaja kita akan arti Seks. Usia remaja memang usia yang sangat rentan terhadap segala sesuatu tindakan positif maupun negatif. Rasa keingintahuan yang tinggi membuat para remaja tersebut membuat mereka ingin mencari tahu apa yang inginkan dan tidak menutup kemungkinan mereka mempraktekkan sesuai dengan apa yang 
diinginkan. Tanpa berfikir panjang, efek baik dan buruk dari segala tindakan yang mereka perbuat seperti perilaku seks pranikah (Taufik, 2013).

Fenomena ini seperti terlupakan dan terabaikan, digerus oleh pergerakan roda modernisasi dalam masyarakat yang mulai terlena dengan rasa individual, konsumerisme, dan turunnya kesadaran sosial. Dunia pendidikan pun seakan membisu seakan memandang permasalahan seks bukan menjadi prioritas utama, dengan ketidak pastian pemerintah melalui Dinas Pendidikan akan kejelasan materi pendidikan seks di sekolah (Jatmikowati et al., 2015).

Di tengah-tengah penyimpangan seks yang begitu meluas pada zaman modern dewasa ini, sudah saatnya meningkatkan pendidikan seks melalui pendekatan keilmuan, rasional, menyampaikan secara terus terang dan apa adanya (tanpa ditutupi-tutupi, dan tanpa tabu), sehingga seks akan menjadi sumber kebahagiaan yang pada gilirannya nanti akan memberikan arti dan makna pada kehidupan. Para resi kita dimasa lalu menggarisbawahi kenyataan bahwa jalan menuju Moksa atau pembebasan hanya dimungkinkan melalui Dharma, Artha dan Kama (Gunawijaya, 2019). Ketiganya tidak bisa dipisahkan karena saling melengkapi satu dengan lainnya.

Widnya dalam pengantar (Suwantana, 2011) Menyatakan bahwa seks yang suci harus dijaga dan dilakukan dengan penuh kehormatan, dilakukan oleh pasangan yang telah menjalani proses inisiasi. Kesucian seks dipelihara dalam peradaban rohani (divine society) dengan menjaga kaum remaja agar tetap dalam keadaan aksata-yoni atau perawan sampai mereka memasuki mahligai perkawinan sebagai pasangan suami-istri yang sah. Dengan demikian, seks yang suci dipelihara dalam tradisi dan seharusnya tradisi yang suci untuk menjaga keperawanan tersebut yang seharusnya diwariskan kepada para generasi muda kita. Hal ini bertolak belakang dengan pola pikir para remaja saat ini, memandang bahwa keperawanan dan keperjakaan serta seks pranikah bukanlah suatu hal yang penting dan sakral, bahkan bukan lagi hal yang tabu untuk dibicarakan. Parahnya lagi, bagi para remaja putra menjadi suatu hal yang membanggakan jika pernah melakukan seks dengan banyak pasangan (Purnamaningsih, 2015).

Untuk memenuhi libido seksual wajib diikuti oleh pikiran dan kesadaran diri seperti ibaratkan kuda yang sangat patuh dengan arahan tali yang dikendalikan sang kusir . Pikiran dan kesadaran diri akan kuat mengarahkan dorongan seksualitas jika pikiran dan kesadaran diri dicerahkan ajaran suci sabda Tuhan.. Ajaran tentang pengendalian seks itu dituangkan dalam berbagai pustaka berupa kitab-kitab Kama Sastra. Terutama di Bali 
memiliki pedoman Kama Sutra sebagai sumber kitab seksologinya Hindu Nusantara, leluhur Hindu telah menurunkan pustaka menjadi acuan lontar seks yang ada di Bali seperti Usada Smaratura, Prasi Dampati Lalangon, Indrani, Smara Krida Laksana, Rukmini Tatwa, Resi Sambina, Rahasia Sanggama, Stri Sesana, Wadu Laksana,, Kama Reka, Kaputusan Sang Hyang Puja Smara Kusuma, Kramaning Alaki Arabi, lontar Ardasmara, Dampati Lalangon,, Pamedasmara, Sanggama Sasana, Cumbana Sesana. (Wiana, 2008)

Pemikiran mendalam yang coba dilakukan dalam melihat berbagai permasalahan yang ada tentang seks, dengan didukung sumber penelitian yang telah dipublikasikan serta sumber buku yang mengulas tentang seks dan filsafatnya, mengarahkan keingintahuan akan beberapa hal, yakni bagaimana kesucian/kesakralan sebuah hubungan seks berdasarkan lontar Resi Sembina, dan bagaimana pandangan masyarakat akan pemaknaan ajaran seks dalam grahasta asrama. Inilah yang kemudian mengantarkan peneliti kepada sebuah usulan penelitian yang mengambil judul "Persepsi Masyarakat Lombok Terhadap Seksologi dalam Ajaran Lontar Resi Sembina Pada Masa Grahasta Asrama (studi ekploratif pada komunitas Hindu di Kota Mataram)".

Masih kurangnya hasil-hasil penelitian yang telah dipublikasikan tentang berbagai nilai-nilai dan ajaran-ajaran moral, khususnya tentang wacana sanggama yang terdapat dalam berbagai naskah lontar Kama Sastra, memunculkan sebuah daya tarik tersendiri untuk diterjemahkan dan dikaji. Dengan harapan dapat dipergunakan sebagai sebuah acuan, referensi atau pedoman dalam pencapaian kehidupan Grahasta Asrama yang harmonis dan bahagia.

\section{Metode}

Dalam penelitian ini digunakan jenis penelitian deskriptif dengan pendekatan kualitatif. Pada penelitian ini membedah sebuah sumber sastra berupa lontar, yang kemudian akan dihubungkan dengan data tentang persepsi masyarakat tentang ajaran ajaran dalam teks lontar Resi Sembina. Data dan objek penelitiannya berupa lontar, data hasil wawancara dari informan serta literatur pendukung lainnya sesuai dengan tujuan atau aspek kajian dalam perumusan permasalahan. Penelitian ini dilakukan di Kelurahan Pagesangan, Kecamatan Mataram, Kota Mataram, Propinsi Nusa Tenggara Barat. Pemilihan lokasi penelitian berdasarkan pertimbangan bahwa dari beberapa daerah yang ada di Lombok khususnya Kota Mataram, etnis Bali atau komunitas masyarakat yang 
beragama Hindu banyak terdapat di lingkungan-lingkungan yang ada di Kecamatan Pagesangan Kota Mataram. Sumber data primer diperoleh langsung dari lokasi penelitian. Sumber ini berasal dari informan. Sedangkan sumber data sekunder berasal dari sumber dokumenter yang meliputi : teks lontar Resi Sembina, arsip dari instansi pemerintah maupun non pemerintah, literatur dan referensi lainnya yang relevan dengan penelitian ini.

\section{Hasil dan Pembahasan}

Pada penelitian ini mencoba untuk menyimpulkan bagaimana persepsi masyarakat yang ada di Kelurahan Pagesangan terhadap sanggama atau kama tattwa, yang nantinya akan coba untuk dihubungkan dengan teks lontar kama sastra yakni Lontar Resi Sembina. Ada tiga indikator yang akan coba digunakan untuk memperoleh data, baik dalam bentuk data primer hasil observasi dan wawancara, maupun dalam bentuk data sekunder berupa data monografi kelurahan dan data lingkungan serta data penunjang lainnya.

Seks dianggap sesuatu kebutuhan biologis fisik belaka, sehingga menghasilkan makna hanya fokus pada proses persetubuhan atau persenggamaan. Sementara itu dimensi seks sesungguhnya menjadi terabaikan. Seks sering disalahartikan, dengan akhirakhir ini seks lebih merupakan hawa nafsu yang bersifat "buruk" dan "jahat" yang merusak dan merupakan sesuatu yang tabu sehingga sanggat tidak pantas untuk dibicarakan dan harus dihindari (Marsono, 2018). Menjamurnya layanan internet tanpa kabel menggunakan teknologi WIFI ditempat umum serta tanpa adanya pengawasan terhadap akses website yang memiliki konten pornografi sedikit banyak berpengaruh terhadap perilaku seks pada orang dewasa (Kasim, 2014).

Makna seks dalam teks Resi Sembina yang tertuang dalam aporisme-aporisme dan simbol-simbol, seperti nama Ra Si Sam Bi Na, Anangga Duta, Windu, dan lain-lain. Makna yang muncul dalam teks ini antara lain: seks sebagai sebuah kebutuhan, sadhana, kesadaran, seks dan pengider buwana, seks sebagai konsep penyatuan, perempuan dan objek pemujaan, kebahagiaan sejati, dan moksa. Seks tidak hanya bermakna badani saja, tetapi lebih pada bagaimana aktivitas tersebut mampu mengantarkan seseorang menuju ruang atau keberadaan yang lebih tinggi dari dimensi manusia itu sendiri. (Suwantana, 2007) 
Penelitian ini memiliki tiga indikator antara lain, pertama tentang pemahaman atau pengetahuan masyarakat tentang tattwa sanggama atau kama sastra, kedua tentang sumber-sumber sastra yang membahas tentang ajaran-ajaran kama tattwa yang ada atau dimiliki oleh masyarakat yang telah masuk dalam kehidupan Grahasta Asrama dan yang ketiga tentang peranan dari sanggama atau pemenuhan kama dalam kehidupan Grahasta Asrama.

\section{Persepsi Masyarakat Lombok Mengenai Tattwa Sanggama Dalam Grahasta Asrama.}

Kehidupan Grahasta Asrama atau berumahtangga oleh (Arini, et all 2019; Sivananda, 2003) dikatakan sebagai tahap yang terpenting dari keempat asrama yang ada. Grahasta Asrama sebagai tempat pembuktian, dari hasil proses belajar dan pendisiplinan diri menuju pencapaian kesiapan diri. Proses ini ditempuh dalam tingkatan Brahmacari Asrama dari manusia itu lahir sampai pada masa dewasanya. Seperti yang disebutkan dalam Manawadharmasastra III.89.90, yang mengatakan "dari kesemua asrama yang ada, Grahasta disebutkan sebagai yang termulia oleh Weda Sruti, sebab ialah yang menjadi penyokong bagi yang lainnya. Sebagaimana sungai-sungai mengalir dan beristirahat di lautan, demikian pula ketiga asrama yang lain mendapat tempat bernaung pada Grahasta" (Pudja, G., \& Sudharta, 2002)

Perkawinan merupakan suatu peristiwa suci bagi seorang Hindu. Dimana istri menjadi rekan bagi suami dalam menjalani kehidupan berumah tangga, menjadi Rama dan Sinta seperti dalam tokoh cerita Ramayana. Dikatakan sebagai yang terpenting karena kompleksnya kewajiban yang harus dilaksanakan oleh sepasang suami dan istri. Salah satu kewajiban dari kehidupan berumah tangga adalah pelaksanaan Panca Maha Yadnya, yakni Dewa Yadnya, Rsi Yadnya, Pitra Yadnya, Bhuta Yadnya dan Manusa Yadnya. Selain itu ada pula kewajiban lain seperti Atithi Yadnya yakni menghormati dan memberikan suguhan pada para tamu (Sivananda, 2003)

Selain itu ada pula kewajiban bagi suami dan istri terhadap keluarganya yang disebut dengan Panca Wida, yakni Sang Ametuaken orang yang melahirkan anak pada kehidupan dunia, Maweh Bhinojana menjamin kebutuhan ekonomi keluarga, Sang Mangupadyaya memberikan pendidikan pada anak sampai moral, mental dan profesi yang nantinya mampu mendukung kehidupannya, Sang Anyangaskara orang yang 
memberikan pendidikan kerohanian dan Sang Matulung urip rikalaning bhaya orang yang memberikan rasa aman dan menolong saat menghadapi bahaya (Santika, 2018).

Secara khusus sesuai dengan penelitian ini, dalam Lontar Resi Sembina dikatakan kewajiban seorang suami adalah mampu menjadi seorang yang Maha Widagda, yakni memiliki pengetahuan akan tattwa dan etika dari sanggama serta seni dalam bercinta. Dengan tujuan mengerti tentang tujuan dan kesakralan sanggama, mampu menjaga kesetiaan dan menghargai wanita atau istri, memberikan berbagai hal yang berhubungan dengan kebutuhan biologisnya dan keharmonisan dari sebuah keluarga.

Mengenai persepsi masyarakat, tentang sejauhmana pengetahuan dan pemahamannya akan Tattwa atau filsafat dari sanggama dalam Grahasta Asrama, berikut hasil wawancara yang peneliti peroleh dari I Komang Matrayana, S.Ag. :

Kama berarti keinginan, cinta atau kasih sayang, kesenangan dari indria, termasuk air mani, dan nama dewa cinta. Sedangkan kata tattwa berarti kesejatian yang membuat sesuatu itu menjadi ada. Hakekat atau jadinya, nyatanya. Jadi dalam pengertian ini, kama tattwa diartikan sebagai hakekat dari kesenangn indria yang terkait dengan cinta. Atau secara sederhana artinya filsafat seks, yang mencakup pendidikan seks itu sendiri. Untuk pendidikan seks yang saya ketahui, dari perkembangan masyarakat Hindu sampai sekarang merupakan usaha untuk mengharmoniskan hubungan suami istri. Dan itu sepertinya bukan suatu hal yang tabu.

Jadi budaya Bali dari beberapa abad yang lalu, merupakan budaya yang memberikan keseimbangan, berdasarkan tingkat kehidupan, yang tentunya mempunyai tujuan masing-masing. Kalau kita misalnya dalam hidupnya pasti memiliki tujuan, demikian juga dengan pendidikan seks itu. Yang bertujuan, satu untuk pencapaian dharma, pencapain artha dan pemenuhan kama atau keinginan. Perlu saya tambahkan sedikit mengenai seks yang baik, ada kata suci, seks yang suci adalah seks yang telah memiliki mata, hati dan pikiran. Demikian juga kama yang suci adalah kama yang ada dalam pelukan dharma".

Seperti yang disampaikan oleh informan diatas, pemahaman akan filsafat dari sanggama atau kama dalam Grahasta Asrama sangatlah baik. I Komang Matrayana menyampaikan dengan lugas akan apa yang diketahuinya pada peneliti. Namun tidak dipungkiri jika dipertanyakan tentang sejauh mana pemahaman dan pengetahuan akan tattwa atau filsafat dari sanggama, yang diketahui oleh masyarakat di Kelurahan Pagesangan, informan hanya menjawab "sangat kurang". Ini didukung oleh hasil wawancara dengan Gede Suta Sumantri, SH, sebagai seorang tokoh masyarakat di Kelurahan Pagesangan. Berikut hasil wawancaranya : 
Mengenai aspek tattwa dari sanggama atau kama, masyarakat lingkungan ini masih kurang tentang itu. Masyarakat kita di sini sudah hampir habis yang suka dengan sastra atau yang mempelajari tentang tattwa begitu, seperti tetua-tetua kita dulu. Yang muda-muda sekarang, disini tidak begitu, seperti yang dulu (ketertarikan mempelajari sastra). Yang dulu tau, seperti tetua kita disini, terkadang juga hanya membicarakan tentang sastra sebatas dengan kelompok atau group pesantiannya atau pepaosannya saja. Masih hanya berkelompok itu saja, sedangkan yang muda-muda kan tidak terjun dengan yang seperti itu. Saya pribadi belum mengetahui atau memahami tentang tattwa sanggama itu.

Pengetahuan atau pemahaman masyarakat akan filsafat agama khususnya Tattwa Sanggama, memang diakui informan masih sangat kurang. Tradisi "Nyastra" atau mempelajari sumber sastra lontar bagi masyarakat setempat, terkadang masih bersifat ekslusif. Hanya untuk kaum Pandita atau orang yang sudah berstatus Dwijati/Sulinggih dan orang-orang Brahmana dalam komunitas Griya saja.

Orang yang dianggap biasa atau masih muda, terkadang tidak diperkenankan untuk ikut membaca lontar atau membahas tentang filsafat agama. Bahkan para orangtua yang telah ikut bergulat dengan sastra yang umumnya termasuk kedalam komunitas Brahmana (Pinandita/Pemangku) juga masih menganggap "Nyastra" itu tidak diperbolehkan untuk orang biasa, apalagi untuk orang yang masih muda. Inilah yang menyebabkan kurangnya pengetahuan dan pemahaman masyarakat akan falsafah dari sebuah ajaran agama, khususnya tentang Tattwa Sanggama atau Kama dalam menjalani kehidupan Grahasta Asrama. Sebagai akibat dari terbatasnya orang-orang yang mau menyumbangkan pengetahuan dan pemahamannya akan ajaran agama Hindu yang berasal dari sastra-sastra lontar inilah, yang menjadi faktor penghambat proses pendidikan dan transfer pengetahuan bagi generasi muda Hindu selanjutnya.

Berikut Kutipan wawancara dengan I Wayan Kota seorang tokoh masyarakat, tentang pemahaman sanggama :

Mengenai sanggama itu kan tidak memaksa istri untuk melakukan hubungan suami istri kan begitu, dan juga ada hari-hari terlarang untuk melakukan hubungan seksual dengan istri kan begitu. Mungkin yang pernah saya dengar itu, purwaning tilem, sama tilem, dan juga purwaning purnama, dan purnama. Dan juga pernah saya baca, ada di kalender saya pernah jumpa, itu untuk tidak boleh melakukan hubungan seksual bersama istri apabila di kalender ada kala mrtyu, dan juga ada sampar wangke. Sampar wangke itu mungkin apabila lahir tidak baik. Kala mrtyu itu kan keras sifatnya. Makanya tidak boleh melakukan hubungan seksual pada waktu itu.

Dari wawancara dengan I Wayan Kota, dapat kita lihat bahwa pemahaman masyarakat, hanya diperoleh dari usaha individu pribadinya dalam mencari pengetahuan 
tentang sanggama. Jadi pemahaman dan pengetahuan yang didapatkan oleh masyarakat dengan cara ini, hanya sebatas sejauh mana kemampuan analisa pribadi dari individunya saja secara otodidak, serta seberapa banyak sumber tertulis yang dimiliki oleh individu tersebut. Terkadang proses pembelajaran yang dilakukan secara otodidak, dapat mengakibatkan pemahaman yang dangkal atau bahkan keliru akan suatu ajaran agama.

Pandangan para pelaku "Nyastra" dan ekslusifisme kaum Brahmana dan Griya, akan lontar atau sumber sastra yang dimiliki, menjadi salah satu faktor penyebab dari kurangnya sosialisasi dan rendahnya pemahaman masyarakat akan pentingnya mengetahui Tattwa dari Sanggama dalam kehidupan berumahtangga bagi pasangan suami istri. I Komang Matrayana dalam kutipan wawancaranya, menyebutkan sebagai berikut :

Mengenai tattwa atau filsafatnya, memang itu harus dipahami, jangan dianggap remeh atau main-main. Untuk susila atau etikanya harus kita jalankan, jangan sampai juga mancla-mencle. Tentang cinta (hubungan suami istri) harus kita rasakan di kedua belah pihak. Jadi kita bisa menemukan kepuasan seks itu, yang mestinya harus kita nikmati. Bukan kita abaikan atau asal-asalan saja. Putra yang baik atau saleh dan pandai membahagiakan keluarganya, itu berawal dari niat, pikiran perasaan orang-orang yang sudah masuk ke dalam Grahasta Asrama tersebut. Kembali ke awal, jika tattwa, etikanya kita sudah pahami. Kita laksanakan dengan rasa cinta kasih sayang yang bagus, dengan etika yang bagus, terlebih dalam sastra juga diungkapkan "yaning putra suputra sadhu gunawan, mamadani kula wandawa". Kalau tidak sejalan tattwa etikanya, tidak mungkin kita akan mendapat anak yang suputra atau yang baik.

Pentingnya pemahaman akan sanggama dalam kehidupan Grahasta Asrama atau berumahtangga, menurut I Komang Matrayana, S.Ag sebagai seorang tokoh masyarakat menjadi perhatian pribadi beliau. Apalagi jika sepasang suami istri ingin memiliki keturunan atau anak yang suputra atau memiliki sifat dan berperilaku baik sesuai ajaran dharma agama Hindu.

Selaku seorang tokoh, informan selain melaksanakan kewajibannya sebagai seorang guru di sekolah dasar, juga meluangkan waktunya dengan membentuk dan mengajak segenap masyarakat di lingkungannya ikut mempelajari sastra agama Hindu. Beliau membentuk sebuah pesantian atau komunitas kidung, dengan harapan semua orang yang ingin mempelajari ajaran agama Hindu dapat ikut serta tanpa terkecuali. khususnya tentang bagaimana menjalani kehidupan berkeluarga yang baik, melalui kidung, palawakya, serta pembacaan sloka.

Pemahaman masyarakat akan ajaran agama Hindu khususnya tentang tattwa atau makna filsafat dari sanggama dalam menjalani kehidupan Grahasta Asrama atau 
berumahtangga di Kelurahan Pagesangan masih sangat rendah. Kurangnya pemikiran terbuka dan ekslusifisme dari para pelaku sastra, baik dalam komunitas pesantian atau pepaosan maupun komunitas Griya oleh para pemuka agama Hindu (para Pinandita dan Pandita), ikut andil dalam rendahnya pengetahuan dan pemahaman masyarakat akan tattwa sanggama, khususnya tentang ajaran Lontar Resi Sembina. Sehingga ajaran tattwa Resi Sembina sebagai salah satu teks Kama Sastra dalam agama Hindu, sebagai sebuah bekal wajib bagi sepasang suami istri dalam menjalani kehidupan Grahasta Asrama, dalam masyarakat Hindu di Kelurahan Pagesangan masih belum diketahui dan dipahami secara baik.

\section{Sumber Ajaran dan Informasi Masyarakat Lombok Mengenai Tattwa Sanggama Dalam Grahasta Asrama.}

Peran sebuah pemikiran dalam menjalankan fungsinya untuk menyempurnakan hidup manusia, jika kita kaitkan dengan kebutuhan manusia akan ilmu pengetahuan dan ajaran agama sangatlah penting. Sebuah pemikiran kritis akan mengajak manusia untuk terus berfilsafat. Mencari jawaban akan arti hidupnya, tujuan hidupnya, bagaimana cara menjalani hidupnya, termasuk siapa yang menciptakan kita dan dunia, bagaimana diciptakan, dan segudang pertanyaan lainnya.

Sebagai jalan keluar dari permasalahan yang dihadapi manusia tentang dirinya, ajaran agama Hindu mengajarkan mengenai sebuah sistem filsafat yang disebut dengan Sad Darsana (Maswinara, 2006). Yang menuntun manusia untuk dapat menggunakan keutamaannya dari mahluk lain yakni "idep" atau pikiran, berbeda dari hewan dan tumbuhan yang hanya memiliki sabda dan bayu saja. Pikiran manusia akan selalu terpacu oleh keadaan dirinya, mencari jati dirinya, mencari makna akan dunia dan kehidupan yang ada diatasnya, terlebih untuk mencari dan memahami Sang Maha Pencipta itu sendiri, melalui segenap panca indria yang dimilikinya (Wiguna, 2020).

Dalam ajaran Sad Darsana salah satu bagianya adalah Nyaya Darsana adalah bagian dari sistem filsafat Hindu yang mendiskusikan kebenaran mendasar melalui 4 cara pegamatan, yaitu : a) Pratyaksa Pramana yakni pengamatan langsung; b) Anumana Pramana yakni pengamatan melalui penyimpulan; c) Upamana Pramana pengamatan melalui perbandingan; d) Sabda Pramana pengamatan melalui penyaksian (Pendit, 2007). 
Bagi sebagian besar manusia, Sabda Pramana menjadi sebuah jalan keluar yang instan dalam memperoleh ilmu pengetahuan. Dengan Sabda Pramana yakni memperoleh pengetahuan melalui kesaksian ( $s a b d a$ ), baik dari seseorang yang dapat dipercaya katakatanya atau pun dari naskah-naskah yang diakui kebenarannya, kita lebih cepat dan mudah dalam memahami sesuatu. Ada dua jenis kesaksian yang diajarkan dalam Sabda Pramana, yaitu : Laukika Sabda, yaitu bentuk kesaksian yang berasal dari orang yang dapat dipercaya dan kesaksiannya dapat diterima menurut logika atau akal sehat, misalnya dharma wacana atau dharma tula oleh para Brahmana atau intelektual Hindu; dan Vaidika Sabda, yaitu bentuk kesaksian yang didasarkan pada naskah-naskah suci Veda Sruti dan Smrti, yang merupakan sabda Brahman yang tak mungkin salah, seperti lontar atau buku dan media lainnya.

Selain pengalaman pribadi dalam mendapatkan dan memahami ilmu pengetahuan dan ajaran agama, kita memerlukan sumber-sumber sastra tertulis dalam mengantarkan pikiran kita agar tidak terjebak kedalam kebodohan atau avidya melalui Sabda Pramana. Sangat banyak ajaran tattwa khususnya tentang sanggama atau kama yang harus kita pelajari dari sumber-sumber sastra yang ada. Rendahnya pengetahuan dan pemahaman umat kita khususnya yang ada di Kelurahan Pagesangan, tidak terlepas dari kurangnya bahan bacaan dan dialog atau diskusi tentang ajaran agama Hindu. Berikut hasil wawancara dengan I Komang Matrayana, terkait dengan rendahnya pemahaman masyarakat akan ajaran sanggama atau kama dalam kehidupan berumahtangga :

Untuk sumber atau literatur sastranya, secara khusus saya tidak punya. Tetapi seingat saya, saya pernah membaca, ada didalam Rukmini Tattwa. Kedua di Lontar Kama Sutra dari India. Ketiga Lontar Pamedasmara. Dapat juga kita lihat di Kakawin Nitisastra dan Putra Sasana, dan masih banyak lagi yang lainnya.

Pendapat diatas didukung oleh pendapat Gede Suta Sumantri, mengenai minimnya sumber sastra baik berupa lontar atau buku tentang tattwa sanggama yang dimiliki masyarakat. Berikut hasil petikan wawancaranya :

Sumber sastra saya tidak tahu dan belum ada yang memberikan pemahaman tentang itu. Saya belum tahu dan tidak memiliki sumber buku atau sastra itu (tentang sanggama atau kama sastra).

Dari hasil wawancara dengan para informan, masyarakat sangat jarang yang memiliki sumber sastra baik buku atau lontar. Berbagai informasi atau pemahaman tentang sanggama, lebih banyak diperoleh dari pembicaraan secara non formal yakni perbincangan-perbincangan ringan dan tidak mendalam. Namun untuk beberapa orangorang tertentu yang menyukai kidung dan pernah ikut dalam perkumpulan pesantian, 
pembicaraan mengenai kama tattwa diperoleh dari pembacaan kidung dan sloka. Berikut hasil wawancara dengan I Komang Matrayana, S.Ag :

Pernah rasanya saya membaca baik tentang orang berbusana, agar orang itu menjadi menarik, atau bisa menarik perhatian orang agar lebih semangat atau lebih jreenglah dari segi seksual itu. Ya mungkin dalam Rukmini Tattwa itu kita akan lebih paham disana. Walaupun saya tidak memiliki lontar atau sastra-sastra atau bukunya itu, saya tidak punya.

Pendapat diatas didukung oleh hasil wawancara dengan I Wayan Kota yang menambahkan beberapa sumber kekidungan atau sloka yang sedikit mengulas tentang prosesi pawiwahan atau perkawinan dan tentang kehidupan Grahasta Asrama :

Kalau lontar mengenai sanggama itu belum pernah saya baca. Tetapi kalau melaksanakan pernikahan itu kan ada api suci itu, dalam sarasamuscaya saya pernah baca. Api suci itu untuk upacara pembakaran mayat, juga untuk upacara nganten (pernikahan) sebagai saksi, itu dikatakan di Sarasamuscaya. Dalam Kekawin Arjuna Wiwaha, kalau tidak salah saya pernah dengar dari kidungnya.

Jadi dapat disimpulkan bahwa masyarakat di Kelurahan Pagesangan hampir seluruhnya belum memiliki sumber sastra yang membahas tentang sanggama atau kama tattwa. Kalaupun ada yang memilikinya, hanya sebatas orang-orang yang ikut tergabung dalam perkumpulan pesantian dan para Sulinggih. Itupun hanya sebatas pada sumber pokok bagi umat Hindu saja sebagai sumber penunjang ajaran kama tattwa, seperti Sarasamuscaya, Slokantara, dan beberapa jenis Kekawin. Untuk yang mengkhusus mengenai tattwa sanggama dan Resi Sembina, sangatlah sedikit.

\section{Pemenuhan Sanggama Masyarakat Lombok Dalam Menjalani Grahasta}

\section{Asrama.}

Kurangnya sumber sastra tertulis baik dalam bentuk lontar dan buku yang dimiliki oleh masyarakat, akan berbanding terbalik jika dikaitkan dengan keingintahuan peneliti mengenai pentingnya pemenuhan sanggama dalam kehidupan berumahtangga suami istri. Berikut hasil wawancara dengan I Komang Matrayana, S.Ag :

Menurut saya pribadi kalau dikatakan penting, ya sangat penting sekali. Ini tidak bisa dianggap sepele, secara psikologi jika itu tidak terpenuhi bisa jadi akibatnya orang itu tidak akan beres jadinya. Pentingnya peran pemenuhan sanggama bagi orang yang telah memasuki Grahasta Asrama atau orang yang sudah berkeluarga, itu menurut saya bukan penting lagi, tetapi sangat penting.

Hasil wawancara diatas sesuai dengan apa yang dikemukakan oleh Wiana dalam tulisannya berjudul "Mengendalikan nafsu seks, menurut ajaran Hindu". Wiana mengatakan ada tiga kebutuhan hidup manusia yang paling menonjol yaitu kebutuhan 
biologis, sosiologis, dan filosofis, diamana ketiga kebutuhan tersebut saling melengkapi. Yang dimaksud dengan kebutuhan biologis, adalah kebutuhan manusia akan makan, minum, dan hubungan seks. Tiga kebutuhan biologis itu tidak bisa lepas dengan kebutuhan sosiologis dan filosofis. Jika pemenuhan kebutuhan biologis tidak berdasarkan aspek sosiologis dan filosofis, manusia bisa diidentikkan dengan hewan (Wiana, 2008)

Begitu juga dengan pendapat dari Gede Suta Sumantri dan I Wayan Kota. Berikut hasil wawancaranya tentang pentingnya pemenuhan sanggama atau seks bagi pasangan suami istri :

Kalau masalah yang begitu, yang tentang pemenuhan sanggama atau kama suami istri itu penting.

Sangat penting pemenuhan kebutuhan biologis itu dalam kehidupan Grahasta. Orang kawin (menikah) kan itu tujuannya, untuk pemenuhan kebutuhan lahiriah lah. Mungkin kalau tidak untuk itu, orang tidak akan kawin (menikah).

Dari seluruh pendapat diatas walaupun minim akan pemahaman tentang makna dan kesucian pelaksanaan sanggama sebagai sebuah kebutuhan biologis manusia, sanggama sebagai sebuah istilah yang digunakan untuk menamai hubungan seksual dari pasangan suami istri, sangatlah lekat, menarik dan sangat diperlukan oleh manusia. Dikuatkan kembali oleh pendapat Wiana dalam artikelnya tentang "mengandalikan nafsu seks, menurut ajaran agama Hindu", yang mengatakan bahwa sanggama sebagai sebuah kebutuhan, adalah memiliki posisi yang sama dengan kebutuhan biologis manusia akan makan dan minum.

Namun kurangnya pemahaman akan tattwa sanggama dan minimnya sumber sastra baik buku maupun lontar yang dimiliki oleh masyarakat, termasuk kurangnya eksistensi para kaum intelektual Hindu yang banyak memahami tentang tattwa sanggama atau kama , menyebabkan adanya keterbatasan pemahaman masyarakat di Kelurahan Pagesangan akan makna, fungsi dan tujuan dari sanggama itu sendiri. Tidak dapat dipungkiri bahwa penyaluran libido atau naluri dan kebutuhan akan seks sebagai pemenuhan kebutuhan biologis manusia, semata hanya didukung oleh minimnya ketersediaan akses masyarakat akan kama sastra. Jadi tidak patut untuk kita persalahkan jika selama ini masyarakat hanya terpuaskan oleh keberadaan berbagai media berbau pornografi saja, sebagai sebuah sarana informasi tentang seks itu sendiri. Walaupun ironis tetapi itulah sebuah fenomena umum yang dapat kita jumpai dalam masyarakat. 
Telaah peneliti dari fenomena sosial di masyarakat sebagai sebuah hasil observasi dalam kehidupan masyarakat diatas, tentang keterbatasan akses akan sumber informasi yang benar dan pemahaman terbatas oleh masyarakat akan tattwa sanggama, didukung oleh hasil wawancara dengan Gede Suta Sumantri, SH. Berikut petikan wawancaranya :

Cuman yang memberikan pemahaman tentang itu (ajaran tattwa sanggama) masih belum ada, siapa yang bisa memberikan. Cuman pernah saya dengar, iseng-iseng saja saya dengar dari mulut kemulut, kalau mau punya anak perempuan atau lakilaki harus begini, harus ada yang dilakukan kalau berhubungan.

Keterbatasan pemahaman ini juga dapat kita jumpai dalam hasil wawancara peneliti dengan I Wayan Kota dan Gede Suta Sumantri, sebagai tokoh masyarakat di kelurahan Pagesangan. Berikut hasil wawancaranya :

Tidak boleh melakukan itu (sanggama) dengan orang lain, jika tidak sah dari perkawinan. Ada jenis perkawinan juga, ada tiga jenis. Ada yang mencuri atau melarikan, saya lupa apa namanya itu. Ada yang memaksa dengan raksasa wiwaha, dan untuk yang baiknya kan meminta ijin orang tuanya, meminta baikbaik ke orangtua si perempuan.

Tentang sanggama atau kama ini belum pernah saya mendengar atau melihat dari media televisi, koran atau media lain. Cuma tadi yang dengar, dari sekedar pembicaraan yang iseng-iseng saja.

Dari berbagai hasil wawancara tentang sanggama yang diperoleh, peneliti masih menangkap kesan bahwa adat masyarakat ketimuran yang masih lekat dalam pola pikir masyarakat kita, menganggap pembicaraan mengenai seksualitas masih tabu untuk dilakukan. Pemikiran yang menganggap seks sebagai hal yang tabu, dapat kita jumpai dengan mencermati penggunaan kata-kata "itu", kata-kata "berhubungan" dan kata-kata lainnya sebagai pengganti istilah sanggama atau seks. Ini disebabkan oleh pemahaman yang masih sempit akan makna, tujuan, manfaat dan ruang lingkup seks itu sendiri.

Masyarakat secara umum bahkan orang-orang yang telah memasuki kehidupan Grahasta, hanya memahami sanggama atau seks sebatas pada pelaksanaan persetubuhan yang terjadi melalui alat kelamin oleh pria dengan wanita saja. Celakanya lagi maraknya peredaran film berbau pornografi semakin memperparah pengetahuan dan pemahaman akan sanggama atau seks itu sendiri. Membentuk persepsi dan opini yang keliru tentang sanggama atau seks. Akibatnya adalah orangtua dalam keluarga sebagai pelaku dan pengguna yang sah menurut negara dan agama, akan pelaksanaan sanggama atau seks itu sendiri, merasa kebingungan dan dilema ketika harus menjelaskan berbagai hal tentang seksualitas kepada anak-anaknya sendiri. Ini dikarenakan mereka sendiri tidak memiliki pemahaman yang baik dan mencukupi tentang tattwa sanggama atau seksualitas. 
I Komang Matrayana dalam hasil wawancaranya, mengemukakan pendapatnya tentang pentingnya penyampaian ajaran kama tattwa melalui media sesuai secara proporsional baik didasarkan pada usia, kepentingan yang dituju, maupun manfaatnya dalam pemecahan munculnya kasus-kasus seksual di masyarakat. Berikut hasil wawancaranya :

Penyampaian tentang sanggama atau kama melalui media seperti cerita, majalah, media televisi atau seperti koran menurut saya pribadi itu positif, lebih-lebih bagi kita-kita yang sudah termasuk dalam katagori kehidupan Grahasta Asrama. Penting juga untuk dapat kita ketahui, dan jangan juga menganggap itu adalah hal yang sifatnya negatif.

Mohon maaf secara pribadi itu sekali lagi bagi saya merupakan hal yang sifatnya positif, untuk media-media yang akan dikonsumsi oleh orang yang masuk katagori berkeluarga. Ya beda kalau misalnya anak-anak yang masih usia-usia remaja yang memang masih belum patut untuk hal seperti itu, ya jangan. Selanjutnya juga kita akan mendapat informasi dari orang-orang yang sebaya atau yang lebih tua dari kita, dari kita bercerita ngalor ngidul lah. Sambil cerita-cerita, bisalah kita mendapatkan informasi-informasi seperti itu (tentang sanggama). Yang di televisi, seperti yang acara dokter Boyke, atau dokter-dokter yang lain. Yang membicarakan tentang seksual. Kita ambil positifnya saja. Jangan terlalu berpikir negatif lah, apalagi pura-pura tidak suka, tetapi sebenarnya suka.

Hal senada juga disampaikan oleh I Wayan Kota dalam hasil wawancaranya, yang mendukung pendapat I Komang Matrayana. Berikut hasil wawancaranya :

Kalau sosialisasi untuk membicarakan (tentang sanggama atau kama tattwa) secara terbuka kan tidak pernah, agak kurang pas kan rasanya (di muka umum). Tetapi sebenarnya bagus sekali untuk sosialisasi, supaya bisa paham, jika melakukan itu (sanggama suami istri) tidak sembarangan. Misalnya istri tidak siap, suami datang-datang dengan pengaruh alkohol (minuman tuak/tradisional) dengan memaksa, sang istri kan tidak berani menolak karena suami sudah tidak terkontrol (terpengaruh minuman keras).

Pemikiran kritis para generasi muda kita, utamanya para remaja yang memiliki rasa keingingintahuan yang tinggi tanpa didasari oleh pemikiran serta pertimbangan yang matang, membuat mereka terkadang bingung dan terlena serta tidak mampu membentengi diri terhadap berbagai pengaruh buruk dari mudahnya akses dan penyebaran media informasi yang berbau pornografi (Putri, 2016). Jika dikombinasikan dengan keterbatasan pemahaman orangtua sebagai pengendali awal, para kaum intelektual baik di sekolah formal dan non formal sebagai pengendali dalam lingkungan mereka, maka tidak dapat dipungkiri lagi jika para remaja mengalami dehumanisasi. Dominasi sifat kebinatangan yang hanya mengandalkan insting seksualnya, akan menganggap sanggama atau hubungan intim adalah wajar, tanpa etika, bebas untuk dinikmati, dan celakanya lagi tanpa memiliki makna dan essensi, hanya sebatas 
pemenuhan kebutuhan layaknya hewan di alam liar. Maka akan muncul pertanyaan, apakah beda manusia dengan hewan yang diklaim oleh manusia memiliki derajat lebih rendah.

Dari pembahasan tentang pentingnya pemenuhan sanggama dalam kehidupan Grahasta Asrama, berdasarkan data yang peneliti peroleh di Kelurahan Pagesangan dapat disimpulkan bahwa terjadi ketidaksesuaian antara pandangan masyarakat akan pentingnya pemenuhan libido seksual sebagai salah satu ekspresi kama dalam kehidupan, dengan pemenuhan sumber informasi baik yang sifatnya utama dalam wujud sastra lontar, buku, dan media sosialisasi lainnya maupun sumber informasi penunjang berupa eksistensi kaum intelektual Hindu dalam penyebaran ajaran tattwa sanggama khususnya tattwa yang terkandung dalam teks Lontar Resi Sembina.

\section{Kesimpulan}

Teks Resi Sambina yang dikarang oleh Ratna Candra ini memberikan tuntunan bagi seorang suami menuju kebijaksanaan yang disebut Sang Maha Widagda, yang memahami tattwa sanggama dan menguasai seni bercinta atau sanggama seperti teknik ciuman, daerah rabaan/sentuhan, titik rangsangan pada wanita (letak G-spot), dan mantra sanggama. Teks Resi Sembina menekankan tentang salah satu swadharma suami adalah memberikan berbagai hal yang berhubungan dengan kebutuhan biologis bagi istrinya. Karena pemenuhan hasrat biologis bagi pasangan suami istri, akan memberikan efek positif bagi keharmonisan rumah tangga.

Persepsi masyarakat tentang makna dari sanggama atau kama sebagai bekal wajib dalam kehidupan Grahasta Asrama masih sangat rendah. Dikarenakan minimnya sumber-sumber sastra, maupun sumber informasi penunjang berupa penyebaran ajaran tattwa sanggama atau kama sastra oleh kaum intelektual Hindu. Kurangnya sosialisasi dikarenakan adanya pemikiran sempit dan ekslusifisme dari para pelaku sastra, baik dalam komunitas pesantian atau pepaosan maupun komunitas Griya oleh para pemuka agama terhadap keberadaan teks-teks lontar yang dimiliki.

\section{Daftar Pustaka}

Adikusumo, I. (2005). Sikap remaja terhadap seks bebas di kota negara: perspektifkajian budaya. universitas Udayana. 
Arini, N. M., Yadnyawati, I. A. G., \& Paramartha, W. (2019). Swadharma grihastha asrama on educating children toward Hindu families. International Journal of Social Sciences and Humanities (IJSSH), 3(3), 10-17.

Duarsa, D. P. (2009). Persepsi Remaja tentang Hubungan Seks Pranikah di Kota Denpasar: Perspektif Kajian Budaya. Universitas Udayana.

Gunawijaya, I. W. T. (2019). TEOLOGI SEKS DALAM PENCIPTAAN KETURUNAN SUPUTRA. GENTA HREDAYA: Media Informasi Ilmiah Jurusan Brahma Widya $\begin{array}{llll}\text { STAHN } & \text { Mpu, 21-29. }\end{array}$ https://stahnmpukuturan.ac.id/jurnal/index.php/genta/article/view/460

I Gede Suwantana. (2007). Seks Sebagai Pendakian Spiritual Kajian Teks Resi Sambina.

Denpasar: Program Pascasarjana IHDN Kerjasama Dengan Sri Kahyangan.

Ida Ayu Made Purnamaningsih. (2015). SEKSUALITAS PELAJAR HINDU PADA MASA BRAHMACARI DI KOTA DENPASAR. Jurnal Pasupati, 4(1), 87-106. Jatmikowati et al. (2015). a Model and Material of Sex Education for Early-AgedChildren. Cakrawala Pendidikan, No. 03, 434-448.

Kasim, F. (2014). Dampak Perilaku Seks Berisiko terhadap Kesehatan Reproduksi dan Upaya Penanganannya (Studi tentang Perilaku Seks Berisiko pada Usia Muda di Aceh). Jurnal Studi Pemuda, 3(1), 39-48. https://jurnal.ugm.ac.id/jurnalpemuda/article/download/32037/19361

Ketut Wiana. (2008). Mengendalikan Nafsu Seks, Menurut Ajaran Hindu. Koran Tokoh. https://phdi.or.id/artikel/mengendalikan-nafsu-seks-menurut-ajaran-hindu

Marsono. (2018). Seksologi Jawa dalam Serat Nitimani dan Relevansinya dengan Pendidikan Seks. In Jayapangus Press.

Maswinara, I. W. (2006). Sistem Filsafat Hindu, Sarva Darsana Samgraha. Surabaya: Paramita.

Pendit, N. S. (2007). Filsafat Hindu Dharma sad darśana: enam aliran astika (ortodoks). Denpasar: Pustaka Bali Post.

Pudja, G., \& Sudharta, T. R. (2002). Manawa Dharmasastra (Manu Dharmasastra). Jakarta: CV. Felita Nusantara Lestari.

Putri, N. A. (2016). Persepsi Seksualitas Kalangan Pelajar SMA/MA di Kota Semarang. Harmony, 1(1), 99-117.

Santika, N. W. R. (2018). Pendidikan Agama Hindu Sebagai Dasar Dalam Pembentukan Karakter. Satya Widya: Jurnal Studi Agama, 1(2), 153-163. 
Sivananda, S. S. (2003). Intisari Ajaran Hindu. Surabaya: Paramita.

Sudarsana, I. K. (2018). Implementasi Pendidikan Informal Hindu Dalam Menjaga Pola Komunikasi Remaja Pada Pergaulan Sehari-hari. Jurnal Komunikasi, 12(1), 4050.

Suwantana, I. G., \& Widnya, I. K. (2011). Seks sebagai pendakian spiritual. Pustaka Bali Post.

Taufik, A. (2013). Persepsi remaja terhadap perilaku seks pranikah (studi kasus SMK Negeri 5 Samarinda). Ejournal Sosiatri-Sosiologi, 1(2), 31-44.

Wiguna, I. B. A. A. (2019). URGENSI KONSELING SEKSUAL BAGI REMAJA HINDU DI ERA MILENIAL. In I. G. Suwantana (Ed.), Teologi Seks Di Era Milenial (Prosiding, pp. 112-122). IHDN PRESS.

Wiguna, I. B. A. A. (2020). Efektivitas Penerapan Metode Hypnoteaching Dalam Meningkatkan Aktivitas Belajar Siswa. PEMBELAJAR: Jurnal Ilmu Pendidikan, Keguruan, Dan Pembelajaran, 4(2). https://doi.org/10.26858/pembelajar.v4i2.13006 